\title{
La última fuga de Patricio
}

\author{
Benjamín Ballester ${ }^{1}$
}

A sus apenas cinco años Patricio Núñez quiso fugarse de la casa. Setenta y cuatro años más tarde, el día ocho de noviembre pasado, volvió a intentarlo, aunque esta vez no estaba su padre para disuadirlo. Su cuerpo logró la ansiada fuga, no así su persona que vivirá con nosotros largo tiempo inmortalizado en sus libros y en la memoria de quienes lo conocimos. Sí, como arqueólogo y materialista considero que la persona excede el cuerpo, trasciende las venas y la carne gracias al obrar, la transformación del entorno, las relaciones, sus enseñanzas y el recuerdo. Es la paradoja del historiador, que de tanto mirar y sumergirse en la historia, deviene finalmente parte de ella para deleite de las generaciones futuras.

La fuga puede parecer para algunos un acto de cobardía y abandono, sin embargo, para mi constituye una posibilidad legítima de cambio, innovación y transformación. Permite el quiebre de lo establecido, el fin de lo cotidiano y el ocaso de la rutina. La fuga es un bastión de libertad y una esperanza en la utopía, en parte rebeldía e insurrección. Es una potencial senda hacia ese otro futuro, a una opción distinta o una nueva oportunidad. Creo que las pulsiones de fuga buscan justamente variar, mutar, alternar, renovar. Suponen por esto un salto, un giro, una revolución; salir de una realidad y entrar en otra. Entendida así, la fuga implica siempre un movimiento desde un estado hacia otro.

Este movimiento genera una distancia entre la posición actual y la precedente. A diferencia del antropólogo que se aleja momentáneamente para observar y estudiar, la fuga implica una separación total. Al ser una pulsión, la fuga nace de una crítica de la realidad anterior para salir de ella y superarla.

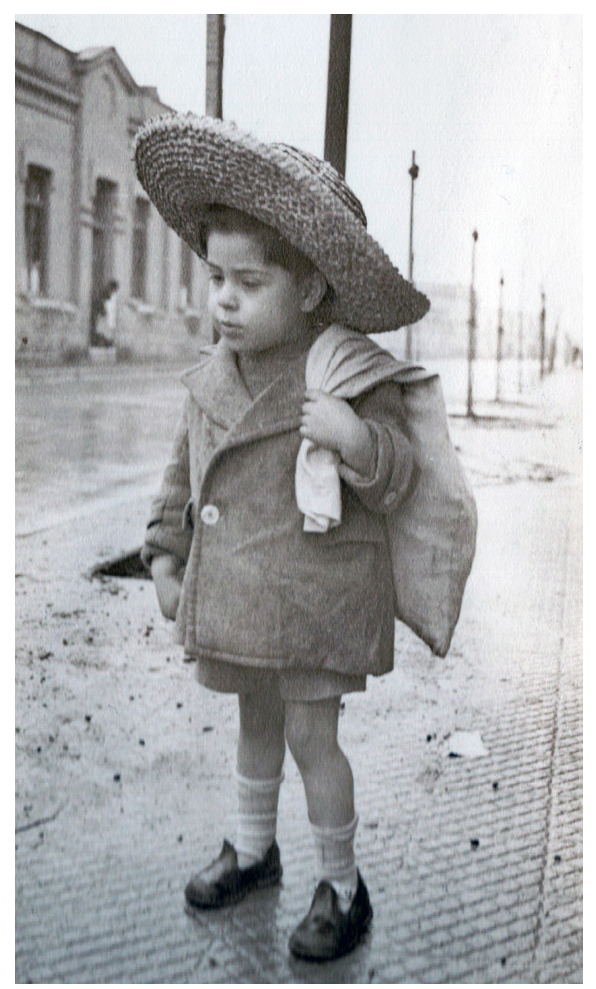

"Pato en fuga". Así venía nombrada la foto al momento de recibirla (cortesía de Guillermo Núñez). 
Desde la nueva condición lejana, la crítica original logra afinarse y perfeccionarse. Las contradicciones vistas desde fuera, ahora con otra perspectiva, devienen más claras y evidentes, ya sin el compromiso con lo propio, interno, cercano y vivido. La fuga puede ser, por lo tanto, una herramienta política para el movimiento y el cambio, de reflexión y crítica, para la construcción de una alternativa y una posición disidente.

Considero que la vida de Patricio fue en cierta medida una fuga perpetua, al menos desde esa primera hazaña cuando tenía cinco años. Él siempre siguió una vía propia, escapando tozudamente de la fuerza centrípeta de la academia y de la inercia de los círculos cerrados de investigadores. En sus pulsiones de fuga buscó albergue en los museos municipales, archivos documentales, aulas de las escuelas, restauración de monumentos, la pasión de los aficionados y especialmente en la escritura de sus libros -únicos en su género en la escena local, dirigidos al gran público sin perder ni una pizca de profundidad y contenido. Estas fugas lo llevaron hacia los temas y sujetos no considerados por la historia tradicional: las mujeres, los niños, los algueros, los recolectores, el textil, el poder, el mar, la pampa, los piratas, la identidad, la artesanía, las dictaduras y, más importante aún, las revoluciones e independencias. Gracias a las pulsiones de fuga logró distanciarse, realizar la crítica y construir una alternativa paralela y vanguardista.
Según sus más cercanos, antes de fallecer Patricio parecía deambular entre múltiples dimensiones, la probable antesala de su última fuga. Durante esos días de desanclaje terrenal, su hermano Guillermo lo visitó y compartieron fotografías en blanco y negro de su infancia. Ante la imposibilidad de hablar, Patricio recurrió a su mejor herramienta de expresión, la escritura, para inmortalizar con un lápiz a tinta azul sobre un cuaderno lo que hoy son sus palabras póstumas: "Hay dos grupos que pelean / Son humanos". Tal como en la fuga musical, donde el sujeto y el contrasujeto se anteponen para crear una unidad sonora, la última fuga de Patricio destacó el antagonismo como motor de las relaciones humanas y del funcionamiento de la sociedad. Dudo que esta frase fuera un delirio previo a la muerte o un preludio de lo que viene después, más bien considero fue una reflexión final acerca de la actual condición humana, un fiel reflejo de los ideales que mantuvo a lo largo de toda su vida.

La habilidad de dar esa lectura de la realidad social y de valorar las pulsiones de fuga son tal vez los legados más significativos que dejó Patricio en mí persona; debido a esto, hoy, la extensión de la suya al cabo de su última fuga.

Agradecimientos: A Guillermo Núñez, Adriana Sáez, Rodrigo Núñez y Carolina Núñez; hermano, pareja, hijo e hija de Patricio. 